\title{
Wood Anatomical Structure of Morus alba L. and Morus nigra L., Native to Iran
}

\author{
Elham KARAMI, Kambiz POURTAHMASI, MahdiSHAHVERDI \\ University of Tehran, Faculty of Natural Resources, Department of Wood and Paper Science and Technology, Iran; portahmsi@ut.ac.ir
}

\begin{abstract}
Iran is a wast country with many different tree species. Among those there are two species of Morus genus including alba and nigra. Since long time ago, white mulberry's wood (Morus alba) has been used for making musical instruments especially bowl shaped instruments in Iran.. In contrast, black mulberry's wood (Morus nigra) has never been used for these types of applications. In order to investigate the possible replacement choices, this study has been carried out to investigate the anatomical differences and similarities between these two species. Wood samples of the two species have been collected from same site and microsections for light microscopic studies and maceration samples have been prepared. The anatomical characteristics were studied according to the IAWA List of Hardwoods. The most important similarities between them are: vessel solitary in short radial multiples or irregular clusters, fiber nonseptate, rays uniseriate and multiseriate type, paratracheal parenchyma, varying from vasicentric to aliform confluent, apotracheal as marginal bands, Rhombic crystals present in rays and sometimes in parenchyma. The main differences are: semi-ring porous distribution of vessels in $M$. alba, fewer number of vessels and presence of aliform parenchyma in $M$. nigra. Taking these results into consideration, the most important features of both species are similar and it could be recommended to use the nigra species as well as the alba for making musical instruments.
\end{abstract}

Keywords: Morus alba, Morus nigra, wood anatomy, musical instruments, bowl shaped instruments

\section{Introduction}

Many musical-instrument makers have long been using wood on the basis of try and error experiences. Recently, scientific people tried to find out the main wood parameters influencing the sound quality of wood (Holz, 1996; Matsunaga et al., 1999; Brancheriau et al., 2006a and b).

Alves et al. (2008) established some anatomical features and physical, mechanical and acoustic properties for pernambuco wood that allow the manufacture of high quality bows and must be considered in the selection of samples of this species as well as other substitute woods.

Recently Longuil et al. (2010) studied the potential of two species for manufacturing bows for musical instruments. According to their results Tabebuia bows can provide quality equivalent to that of pernambuco wood.

Mulberry's wood has long been used in Iran for making bowl shaped musical instruments. The genus Morus L. (Moraceae), represented by 13 species, is distributed almost throughout the world especially in temperate and tropical zones of Asia and Africa (Mabberley, 2008). It occurs in various forest types, from sea level up to 2500 m (Ter Welle et al., 1986). Ter Welle et al. (1986) studied anatomical features of all genera of the family Moraceae. In their research, anatomical features of the species of the genus Morus were described. The genus Morus includes two species in Iran: Morus alba L. and Morus nigra L. that could grow from north to south of Iran, depending on climatic situation; in the areas with enough water availability
(Pourtahmasi and Segolpayegani, 2009). They can grow in full sun or light shade in almost any soil. Among these two species M. alba is the main species for making traditional bowl shaped musical instruments (Taar, Setaar and Kamanche) in Iran (Pourtahmasi and Segolpayegani, 2009) whereas no one has ever used black mulberry's wood for making musical instruments. Therefore this study has been done to compare the anatomical properties of both species and to find out the main similarities and differences for a possible substitution.

\section{Materials and methods}

Wood samples of White Mulberry (Morus alba) and Black Mulberry (Morus nigra) were collected from the Karaj-Chalous road, 12 kilometers north of Karaj city, Iran. The anatomical properties were studied using light microscopy. Wooden samples were cut with dimensions: 2 $\mathrm{cm}(\mathrm{L}) \times 2 \mathrm{~cm}(\mathrm{R}) \times 2 \mathrm{~cm}(\mathrm{~T})$ and then using a microtome, microsections were prepared. Sample preparation and coloring of the microsections were done using Parsapajouh et al. (2006) method. Small chips of woods were also prepared for maceration according to Franklin (1945). In general, quantitative features were based on 30 measurements or counts per character; however, lengths of axial elements are based on 50 measurements of each cell type. Terminology used is in accordance with the list of microscopic features for hardwood identification (IAWA committee, 1989). 
130

Results

\section{Wood anatomy of M. alba (Fig. 1-5)}

Wood is semi-ring porous, growth ring boundaries are distinct. Vessels are mostly multiples (sometimes solitary) in radial direction or clusters of 2-4 cells in earlywood (rarely 8 cells) and sometimes in diagonal groups in latewood. The average number of vessels is 30 (20-39) per $\mathrm{mm}^{2}$ in the earlywood and more than 100 in the latewood; average tangential $\mathrm{x}$ radial diameter is $192(100-290) \mu \mathrm{m}$ x $238(100-300) \mu \mathrm{m}$ in the earlywood, and $63(50-90) \mu \mathrm{m}$ x $59(30-190) \mu \mathrm{m}$ in the latewood. Average vessel element length is $253(150-387) \mu \mathrm{m}$; perforation plates are simple.
Intervessel pits are mostly alternate, of medium size (5-10 $\mu \mathrm{m}$ vertical diameter). The narrower vessel walls have helical thickenings. Vessel-ray pits have much reduced borders to apparently simple, pit outline rounded or angular, smaller than the intervessel pits. The fiber length is 1098 $\mu \mathrm{m}$, fiber elements include nonseptate libriform fibers. Axial parenchyma are extremely rare, paratracheal axial parenchyma is found in vasicentric form. Rays are 8 (6-11) per $\mathrm{mm}$; both uniseriate and multiseriate; homocellular rays consist mostly of procumbent cells; rays are sometimes heterocellular with a few square cells; uniseriate rays are about $90 \mu \mathrm{m}$ tall; multiseriate rays are $142(133-150)$ $\mu \mathrm{m}$ tall and $4-12$ cells wide. Crystals in the rays and axial parenchyma are present.
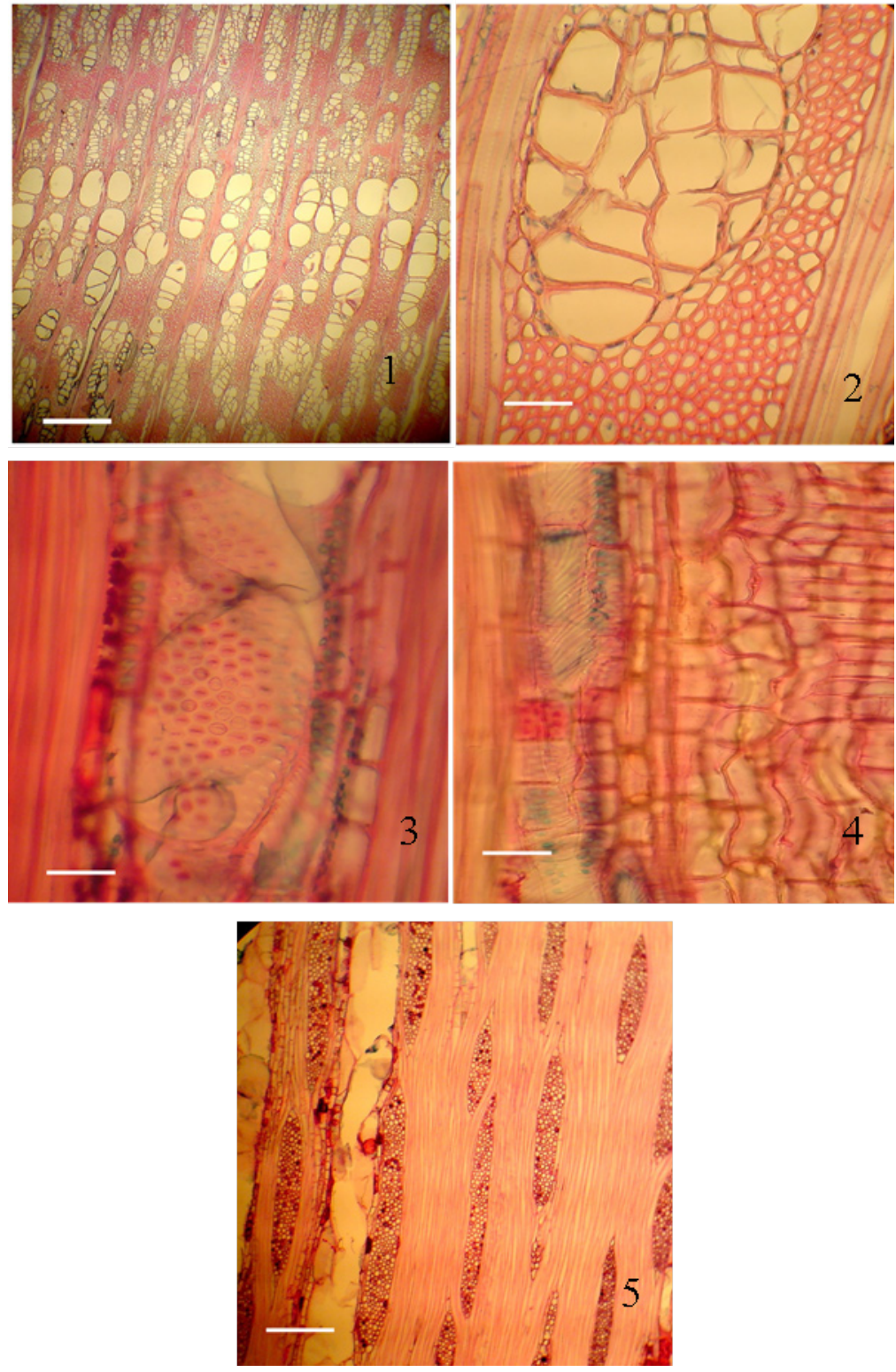

Fig. 1-5. Microscopic sections of Morus alba; 1-Transverse section; 2-Wall thickness of fibers; 3-Alternative vessel pits; 4-Helical thickening; 5-Tangential section; Scale bars $=100 \mu \mathrm{m}$ 
Wood anatomy of M. nigra (Fig. 6-9)

Wood is ring porous, growth ring boundaries are distinct. Vessels are mostly multiples (sometimes solitary) in radial direction of 2-6 cells in earlywood and sometimes in cluster groups of 2-7 (rarely more than 7) in latewood. The average number of vessels is $16(15-20)$ per $\mathrm{mm}^{2}$ in the earlywood and 30 (25-34) per $\mathrm{mm}^{2}$ in the latewood; average tangential $\mathrm{x}$ radial diameter is $27(21-36) \mu \mathrm{m} \times 36(22-$ 56) $\mu \mathrm{m}$ in the earlywood, and $13(8-16) \mu \mathrm{m} \times 22(12-30)$ $\mu \mathrm{m}$ in the latewood, Perforation plates are simple. Intervessel pits are mostly alternate, of medium size $(5-10 \mu \mathrm{m}$ vertical diameter). The narrower vessel walls have helical thickening. Vessel-ray pits have much reduced borders to apparently simple, pit outline rounded or angular, smaller than the intervessel pits. The fiber length is $1298 \mu \mathrm{m}$, fiber elements include nonseptate libriform fibers. Axial parenchyma is diffuse, paratracheal axial parenchyma is found in vasicentricform, axial parenchyma in marginal bands and aliform parenchyma are present. Rays are 8 (7-9) per $\mathrm{mm}^{2}$; both uniseriate and multiseriate; homocellular rays mostly consist of procumbent cells; rays are sometimes heterocellular with a few square cells; uniseriate rays are about $76 \mu \mathrm{m}$ tall; multiseriate rays are $119(103-158) \mu \mathrm{m}$ tall and 4-8 cells wide. Prismatic crystals in square ray cells and axial parenchyma are present.

\section{Discussion}

Comparison of the wood anatomy results with the other species of Morus

Noteworthy differences between woods of $M$. alba and the other species studied by Ter Welle et al. (1986) include: diffuse porous distribution of vessels and absence of spiral thickenings in $M$. insignis; presence of aliform parenchyma in $M$. macroura; diffuse porous distribution of vessels, absence of helical thickenings and presence of parenchyma in wavy bands in $M$. meozygia; ring porous distribution of vessels and presence of aliform parenchyma in $M$. rubra. Differences between woods of $M$. nigra and the other species studied include: diffuse porous distribution of vessels and absence of aliform paranchyma in $M$. insignis, diffuse porous distribution of vessels and presence of helical thickenings in $M$. macroura, diffuse porous distribution of vessels and absence of aliform parenchyma in $M$. meozygia, and presence of helical thickenings in $M$. rubra.
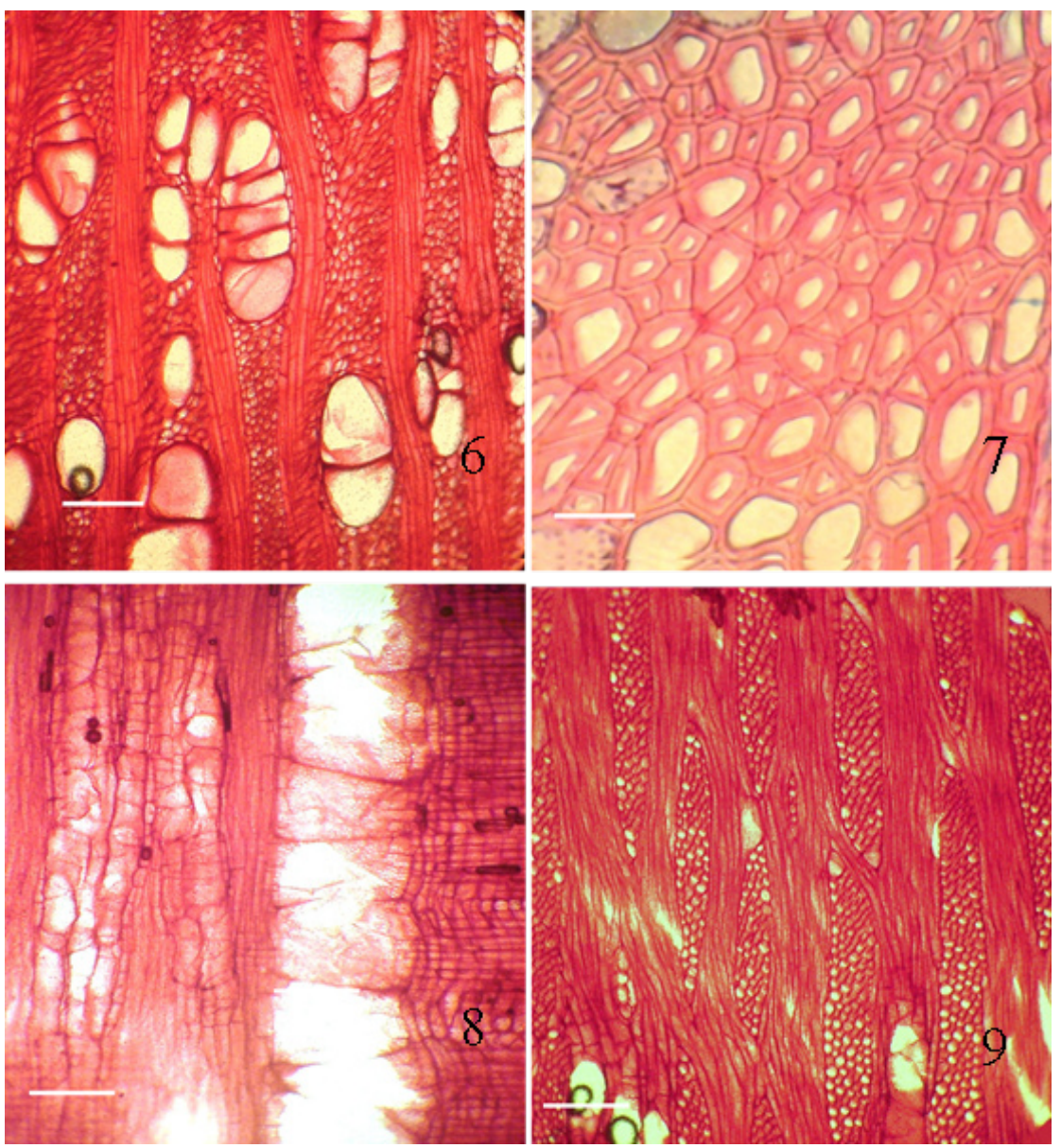

Fig. 6-9. Microscopic sections of Morus nigra; 6-Transverse section; 7-Wall thickness of fibers; 8-Radial section; 9-Tangential section; Scale bars $=100 \mu \mathrm{m}$ 
132

Comparison between the two species of this study

From the material available for this study, it is obvious that the woods of these species are mainly similar to each other and there are very few differences. The main differences between woods of $M$. alba and M. nigra include: semi-ring porous distribution of vessels in $M$. alba, fewer number of vessels and presence of aliform parenchyma in M. nigra.

According to the results of Brancheriau et al. (2006a and b) the axial parenchyma was found to be mainly paratracheal in the good acoustic woods, ranging from scanty paratracheal (Calophyllum, Commiphora and Swietenia) or lozenge-aliform (Dalbergia, Pseudopiptadenia and Simarouba) to highly abundant and very confluent, forming wide bands linking vessels (Hymenolobium). In our results we also found mainly paratracheal form of the axial parenchyma and this is a good reason for using the white mulberry's wood for manufacturing musical instruments. These results are also in agreement with other researches carried out on white mulberry (Pourtahmasi and Segolpayegani, 2009; Roohnia et al., 2007).

Because there are not important anatomical differences between the two species, use of $M$. nigra as well as $M$. alba can be recommended for making musical instruments.

\section{Conclusions}

Wood anatomy of two native Iranian species of Morus has been studied. The results revealed small differences between these two species in vessel distribution and frequency and existing of aliform axial parenchyma cells. According to the results and based on anatomical features, the black mulberry could also be used for making bowl shaped musical instruments. Further investigations on physical, mechanical and acoustic properties of these species would help to confirm the results.

\section{Acknowledgments}

The authors would like to thank the two anonymous reviewers, for their useful comments on the article and Dr. Mehdi Tajvidi for his help on English revision of the article.

\section{References}

Alves, E. S., E. L. Longui and E. Amano (2008). Pernambuco wood (Caesalpinia echinata) used in the manufacture of bows for string instruments. IAWA J. 29:323-335.
Brancheriau, L., H. Baillères, P. Détienne, J. Gril and R. Kronland (2006a). Key signal and wood anatomy parameters related to the acoustic quality of wood for xylophone-type percussion instruments. J. Wood Sci. 52:270-273.

Brancheriau, L., H. Baillères, P. Détienne, R. Kronland and B. Metzger (2006b). Classifying xylophone bar materials by perceptual, signal processing and wood anatomy analysis. Annals of Forest Science 63:73-81.

Franklin, G. L. (1945). Preparation of The Sections of Synthetic Resins and Wood-Resin Composites, and a New Macerating Method for Wood. Nature J. 155:51-51.

Holz, D. (1996). Tropical hardwoods used in musical instruments - can we substitute them by temperate zone species? Holzforschung J. 50:121-129.

IAWA Committee. (1989). IAWA list of microscopic features for hardwood identification. IAWA Bull. N.S. 10:219-332.

Koidzumi, G. (1917). Taxonomical discussion on Morus plants. Bull. Imp. Sericult. Exp. Stat. 3:1-62.

Longui, E. L., T. Yojo, D. R. Lombardi and E. S. Alves (2010). The potential of ipê (Handroanthus spp.) and maçaranduba (Manilkara spp.) woods in the manufacture of bows for string instruments. IAWA J. 31(2):149-160.

Mabberley, D. J. (2008). Mabberley's Plant-Book. A Portable Dictionary of the Vascular Plants, their Classification and Uses. Third Edition. Cambridge University Press, UK.

Matsunaga, M., K. Minato and F. Nakatsubo (1999). Vibrational property changes of spruce wood by impregnating with water-soluble extractives of pernambuco (Guilandina echinata Spreng.). J. Wood Sci. 45:470-474.

Parsapajouh, D., F. H. Schweingruber and O. Lenz. (1987). Atlas of northern Iranian wood, University of Tehran Press.

Pourtahmasi, K., A. Segolpayegani (2009). Introducing Mulberry's wood (Morus alba L.) used in bowl shaped musical instruments of Iran. Actes de la journée d'étude. Le bois: instrument du patrimoine musical-Cité de la Musique, Paris.

Roohnia, M., J. Gril, I. Bremaud and N. Manouchehri (2007). Sound velocity for evaluating a piece of wood in acoustical performances, pp. 209-215. Proceeding of third international symposium on wood machining.

Ter Welle, B. J. H., J. Koek-Noorman and S. M. C. Topper (1986). The systematic wood anatomy of the Moraceae (Urticales) V. Genera of the tribe Moreae without urticaceous stamens. IAWA Bulletin 7:175-193. 